Van Gorp, B., Emons, P., Rommes, E. (2014). From the wizard to the doubter: Prototypes of scientists and engineers in fiction and non-fiction media aimed at Dutch children and teenagers. Public Understanding of Science, 23 (6), 648-661. doi: 10.1177/0963662512468566

\title{
From the wizard to the doubter: Prototypes of scientists and engineers in fiction and non-fiction media aimed at Dutch children and teenagers
}

The aim of this paper is to gain insight into the prototypical scientists as they appear in fiction and non-fiction media consumed by children and teenagers in the Netherlands. A qualitativeinterpretive content analysis is used to identify seven prototypes and the associated characteristics in a systematic way. The results show that the element of risk is given more attention in fiction than in non-fiction. Also, eccentric scientists appear more often in fiction. In non-fiction, the dimension useful/useless is more important. Furthermore, fictional scientists are loners, although in reality scientists more often work in a team. In both fiction and non-fiction, the final product of the scientific process gets more attention than the process itself. The prototype of the doubter is introduced as an alternative to the dominant representations because it represents scientists and engineers in a more realistic and nuanced way. 


\section{Introduction}

According to European research, the negative image of science, engineering, and technology in society is one of the main reasons for young people's lack of interest in science (Van den Berg et al., 2003). The low number of women students and female employees in these domains is a special cause for concern. In 2003, the Netherlands has one of the lowest number of women graduates $(16 \%)$ compared to other EU countries, whereas the US has one of the highest scores (38\%) of the OECD countries (Working Group on the Declining Interest in Science and Technology (S\&T), 2006). Similarly, in 2007, less than 7\% of the grade A academic staff in natural sciences in the Netherlands is female, which is among the lowest numbers in the EU (the average percentage is 13.4\%) (European Commission, 2009, p. 79).

The "self to prototype matching" theory provides a possible explanation for choices of profession (Hannover and Kessels, 2004; Kessels, 2005). According to this theory, people compare the images they have of themselves and of who they want to be with a prototype of someone who has made a certain choice. If the (desired or future) self-image and prototype lie closer to each other, a choice in that direction is more likely. One could therefore say that a choice of profession is a choice of identity (Schreiner and Sjoberg, 2005).

A prototype is a kind of "ideal type" of a group of people. Prototypes of scientists and engineers contain all the stereotypes of a person in these professions, including aspects that are irrelevant to their professional roles, such as sex, ethnicity, appearance and attractiveness. They are so powerful that even if young people have family members working in the profession who do not fulfil the prototype, this does not influence its effect (Rommes, Overbeek, Scholte, Engels and de Kemp, 2007).

Chambers (1983) developed a test in which children were asked to draw a scientist (the Draw-A-Scientist Test). From his research, a number of characteristics emerged that 
constitute the stereotypical image of the scientist, for instance, as a person in a white coat. Images of science as dangerous and as associated with secrecy also appeared regularly. This research has been repeated several times in different countries among children and young people of different ages and in different years, with similar results (e.g., Finson, 2003; Fralick, Kearn, Thompson and Lyons, 2008; Lafosse-Marin \& Laguës, 2007; Rommes and Schönberger, 2009). Furthermore, various characteristics occurred repeatedly in the descriptions young people gave of these drawings. Scientists were depicted as ugly, not fashionable and not interested in their appearance; scientists are alone, isolated and unsociable; and scientists seem to be obsessed and completely absorbed by their work.

\section{Aim of the study}

The media constitute an important source of information and opinions on which this image is based. The available analyses to date on media content indicate that scientists and engineers are shown less than other professional groups and that they are often presented in a stereotypical and negative way (Kitzinger, Haran, Chimba and Boyce, 2008; Michel and Pelka, 2004).

Certain findings emerge from earlier research into patterns in stereotypical characteristics of scientists in fiction. In the more popular genres, including comic books and science fiction, the image of the scientist is the most stereotypical (Basalla, 1976). Scientists are rarely appointed the hero's part, but they do have great power and may control supernatural powers. The representation of the scientist in motion pictures turns out to be the most varied. Probably, this is connected with the existing diversity in film genres. Therefore, characterisations seem to contradict each other at times. On the one side, there is the rather realistic image of scientists, especially concerning appearance, and the lack of a representation of science as something magical, mysterious or bad (Hirsch, 1958; Long and 
Steinke, 1996; Steinke, 2005). On the other hand, Weingart determined that the most striking characteristic of scientific research as presented in films is the threat it holds for humanity: "The content of movies is, indeed, driven to a considerable extent by basic myths about the creation of new knowledge, its boundaries, and the dangers of trespassing those boundaries" (Weingart, 2003: 286).

LaFollette (1990) tried to discover a system in the cultural prototypes of the scientist in the media: the scientists as wizard, as expert, as creator/destroyer and as hero. A constant factor in all these types was that they work hard and are willing to make personal sacrifices. Haynes (2003) called the representation of a scientist as a bad and dangerous person a master narrative. She distinguished between seven prototypes in her study of the representation of scientists in Western literature: the evil alchemist; the noble scientist as hero or saviour of society; the foolish scientist; the inhuman researcher of romanticism; the scientist as adventurer; the mad, bad, dangerous scientist; and the helpless scientist. From this enumeration, it appeared that the representation of science is complex and linked to certain fears that are perpetuated in society beyond time and place. Moreover, scientists in fiction are generally old white males (LaFollette, 1990). In the few cases in which the scientist was a woman, the prototypes were rather different from those of male scientists, leading Flicker (2003) to introduce a distinction between six types of representations of the female scientist: the old maid, the masculine woman, the naive expert, the evil plotter, the daughter or assistant, and the lonely heroine. Concerning their appearance, the female scientists are noticeably younger (and more attractive) than their male counterparts, which is a common difference between male and female characters on Dutch television (Emons, Wester and Scheepers, 2010).

The enumerations of stereotypes of scientists and the typologies described in the literature are based on fiction genres. The aim of this paper is to examine to what extent these 
typologies are also reflected in non-fiction genres and how the representation of scientists in fiction and in non-fiction relate to each other. Turney (1998) argued that the public's perception of science is fed by both non-fiction (e.g., newspapers and magazines) and fiction (e.g., literature and movies); and that representations in fiction form a basis for subsequent representations in non-fiction. He referred to Frankenstein, the novel Mary Shelley published in 1818 , which shaped the ambivalent attitude towards new scientific developments in nonfiction. He cited a range of examples from the newspapers, including news reports on organ grafting, in vitro fertilisation, cloning, and genetic engineering, that implicitly or explicitly used Frankenstein and the "creation of life" myth as a frame of reference.

In this paper, we will explore which prototypes are popular in fiction and in nonfiction. The main assumption is that the representation of scientists in non-fiction genres, such as informative TV programmes and the popular press, is the result of (un)conscious choices by media producers, influenced by prototypes in fiction. We presume that producers of nonfiction tap into the familiar imagery of science and technology in fiction to appeal to children and teens by making scientists easily recognisable.

An overview of generic prototypes in both fiction and non-fiction genres could be useful for the formulation of an answer to the question of why science and technology are perceived by young people as unattractive professions. In this study, the research question was formulated as: Which prototypes of scientists and engineers are dominant in Dutch media aimed at children and teenagers, and what are the differences between fiction and non-fiction media? We started our analysis by focusing on character traits and appearances of prototypes we found in Dutch (non-)fiction media. From these prototypes, we distilled five prominent characteristics of science and scientists that recur to a greater or lesser extent in each prototype and hence may become defining characteristics of the understanding of science and technology in Dutch society. 


\section{The search for prototypical scientists}

\section{Sample}

When collecting the material for analysis, we have strategically searched for as broad as possible a gamut of media used by children from primary school and secondary classes (618 years) in the Netherlands, provided that scientists or engineers were represented. Most material was originally produced in the Netherlands. We mainly selected items that are still commercially available in the general bookstores, DVD shops, etc. As a result, we are not able to distinguish between the synchronic variety of prototypes and the diachronic variety in the typology. Because we were interested in the variety between prototypes, variation of the sample was more important than completeness and representativeness. We used several research strategies to make a sample.

Non-fiction. A random sample of episodes, broadcast between 1989 and 2009, of the three most popular Dutch infotainment television programmes aimed at children and teenagers was analysed: Het Klokhuis $(n=186)$, Willem Wever $(n=110)$, and Jules Unlimited $(n=100)$. The programmes were broadcast on the Dutch national TV channels, Het Klokhuis since 1990 on NPS/NTR, Willem Wever since 1994 on NCRV, and Jules Unlimited between 1989 and 2004 on VARA.

Non-fiction and fiction are strongly intertwined in Het Klokhuis and Willem Wever. The TV producers introduced fictional scientists, played by actors, in the programmes. They are involved in funny situations that probably compensate for the seriousness of the instructive parts.

Furthermore, we included $K I J K$, the monthly Dutch magazine dedicated to science and technology that was established in 1968. Of each edition of the magazine between 1989 and 2009 , we randomly chose one copy a year and analysed all 241 articles that were related to 
science and technology. We also took one recent issue of the periodicals Eos Magazine, Explore, National Geographic Junior, Quest, the Dutch version of Scientific American and Wetenschap in beeld.

Fiction. The fiction material that we studied included comic books, children's books, television series and motion pictures containing representations of scientists and engineers. Comic books. We made an inventory of all comic books series that are popular and readily available in the Netherlands and in which at least one of the main characters is a scientist or an engineer. From these series, we selected the album in which the character is introduced, most often the first issue, and at least one album in which the character plays a central role because most often scientists are not the lead character. The following comicbook series were included in our sample: ("Dutch title" [original title] (authors - country of origin, year of first issue/year of first appearance of scientist/engineer): "Blake en Mortimer" [Blake et Mortimer] (E.P. Jacobs - Belgium, 1946), "Donald Duck" (C. Barks et al. - US, 1934/1952), “Kuifje” [Tintin] (Hergé - Belgium, 1929/1944), “De Smurfen” [Les Schtroumpfs] (Peyo - Belgium, 1959), and "Suske en Wiske" (W. Vandersteen - Belgium, $1945 / 1948)$.

Children's books. A collector of children's books and a librarian helped us find books with a scientist or engineer as a lead character. Four books were included in the sample; one of them was a Dutch translation of an international bestseller ("Dutch title" [original title] (authors - country of origin, year of publication in the Netherlands): "Professor Knap en zijn super-auto" (T. Van Brussel \& W. Van den Berg - the Netherlands, 1997), "Ik ben Kaat!! Uitvinder" (T. Gladdines - the Netherlands, 2007), "Professor Kopstuk" (F. Herzen - the Netherlands, 2001), and “Dr. Proktor's schetenpoeder" [Doktor Proktors Prompepulver] (J. Nesbø - Norway, 2007). 
$T V$ series. We made use of the national archives of Dutch television

(archieven.beeldengeluid.nl) and internet resources (www.kindernet.tv,

www.televisieseries.com, www.youtube.com) to make an inventory of all children and youth series that have been broadcasted on Dutch television with a scientist as a leading character since the 1960s. We counted five series (translated title, country of origin, year of production/year of broadcast in the Netherlands), starting with De avonturen van Okkie Trooy (the Netherlands, 1962) and including the successful series De wonderlijke avonturen van Herman van Veen (Germany, 1977/1979), Doctor Snuggles (The Netherlands/Germany, 1979), and Professor Poopsnagle (Australia/France, 1986/1989). The Dutch series Bassie en Adriaan en de huilende professor (1982) is still available on DVD and was included in the sample. We were only able to analyse clips from episodes of the older series and the abstracts that are available in the Dutch television archives and on the internet.

Movies. During our research, we have found 13 movies made in the Netherlands with a relationship to science and technology. The abstracts of all the movies were analysed, but only the four movies that were successful at the box office and that are still available on DVD were included in the sample (Title, director, year of release in the Netherlands): Peter en de vliegende autobus (K. Van der Meulen, 1976), De lift (D. Maas, 1983), The discovery of heaven (J. Krabbé, 2001), and Verder dan de maan (S. Coninx, 2003).

\section{Data analysis procedures}

The method used in this research is a qualitative-interpretive content analysis, whereby we have inductively identified a number of prototypes and associated characteristics and dimensions in a systematic way. This was done in four parallel phases.

First, we made an inventory of items for each genre, and then we started the analysis on the basis of a small subsample. In the course of the analysis, we expanded the corpus and 
continued with selecting items from our inventories until we reached a point of saturation for each prototype.

In a second phase of the analysis, different aspects of each representation of a scientist or engineer were systematically recorded. We first answered the questions about: who, what, where, when and why: indicators referring to who the scientists and engineers are, along with others concerning their appearance; the indicators that were related to their activities and where and when they executed them; and finally, the indicators that explained something about their motives. Secondly, we studied the position of the scientist within the story by linking it to the classical narrative role such as the hero, the villain and the helper (cf. Propp, 1958). We included relevant quotations and descriptions of images in a database and we recorded interpretations in memos. The preliminary results were compared in order to discuss them with the research team.

In a third phase, we looked for patterns in the extensive inventory of indicators by distinguishing them, on the one hand, in clusters of recurring characteristics fundamental to the prototypes and, on the other hand, in dimensions indicating how the different prototypes are related to each other.

We finally decided not to make a strict distinction in the typology between engineers and scientists, since, as in the prototypes, different professional groups regularly appear together. It is for good reason that, in science and technology studies, the term "technosciences" has been introduced and been in use for quite some time, as it emphasises the inextricable interrelation between scientific knowledge and technology (Hottois, 1984; Ihde and Selinger, 2003).

\section{Results}

Seven prototypes 
An inventory of the real experts in the three non-fiction television programmes in our sample showed some "constants": $78.7 \%$ of the scientists and technicians is male and $96.3 \%$ is white/Caucasian ( $n=381)$. Over time (1989-2009), however, we found that the proportion of experts between 19-35 years old increased (from $20 \%$ to $40 \%$ approx.) and the share of experts between $36-65$ years decreased (from $80 \%$ to $60 \%$ approx.). In sum, regardless of the prototype to which experts may belong, they can be characterised as white and male.

The inductive analysis of both the fiction and non-fiction media resulted in the identification of seven prototypes: the genius, the nerd, the puzzler, the adventurer, the mad scientist, the wizard, and the misunderstood genius. Table 1 gives an overview of the results. In what follows, it will be demonstrated that some particular properties of scientists are emphasised in fiction, but that the same characteristics may also be reflected in non-fiction. However, in fiction genres, they are enlarged and represented in stereotypical characteristics or incorporated in a caricature prototype, using, among others, specific physical characteristics and symbols. The prototypes are hereinafter illustrated with a number of excerpts from the studied samples (all translations were made by the authors).

\section{[TABLE 1 ABOUT HERE]}

The genius. The prototype of the scientist eliciting the most admiration is the genius, with the brilliant inventor as a variation in the category of engineers. In fiction, the exceptional achievements of the genius are visualised by all kinds of fantastic inventions, often means of transportation, such as the Terranef, to travel underground (from the comics series Suske en Wiske). Their achievements turn geniuses into super people. However, to be capable of such superhuman performances, it is also insinuated that they distance themselves from the material world. In fiction, this characteristic often takes the form of absentmindedness or confusion regarding everyday affairs, which symbolises their detachment from 
the world in which ordinary people live. Herzen described a professor in a children's book as having:

An amazingly wise head! A brilliant head with ten thousand ideas. These ideas always wanted to escape from it. Because that was clearly not possible, it was a mess in that head. The professor himself was little affected by it. But the people he dealt with all the more (Herzen, 2001, p. 4).

Many fiction authors use the absent-mindedness and detachment from the ordinary world of the professor/inventor either to make him the comical note in the story or to use him as the driving force for the plot, for instance, when his inventions lead to dangerous situations as these get out of hand. Interestingly, the confusion of the genius is not a characteristic related to scientists in non-fiction, whereas it is a major theme in much fiction.

In non-fiction, contemporary scholars rarely are presented as "geniuses"; they are much more modest. The inventions of science are marked as "brilliant", not the inventors themselves. They seem to achieve their goal especially when they work together, for instance: "In Switzerland, at CERN, thousands of scientists are trying to find answers to the question of how the universe arose" (Van Lieshout et al., 2009).

The nerd. A second manifestation of the disengagement from the material world is that the scientist is maladaptive or socially inept. This feature is enlarged in and forms the basic component of a second prototype: the nerd. Disengagement also symbolises the scientists' dedication to his work, as for example in one of the children's books in the sample: "Suddenly he realised why he [inventor Otto] did not like birthday parties. This is why! What a terrible noise! How could he possibly think with all that noise?” (Rompa, 2008, p. 30).

In fiction, lack of social skills is a defining component of the nerd, as is their intelligence and competence in their chosen subject. Because they deviate from the norms for social behaviour in many respects, they can still come across as "stupid" to others. However, 
it sometimes seems that the reaction of others does not bother them. Unlike the genius, however, the nerd also has opponents and he mostly works with computer technology, which is seen as less spectacular and sexy. Both in fiction and non-fiction, the nerd cannot count unconditionally on power and status like the genius. For instance, in KIJK (Piekart, 1998), it was even Bill Gates who was, despite his fortune and software empire, ridiculed as the “American super nerd".

The puzzler. Puzzlers are as obsessed as nerds. They do not work with computer technology as much, preferring to work with riddles. The puzzler is the personification of a number of specific features of the scientist or engineer: the endless patience to solve enigmas, the structure and precision applied and the satisfaction he finds in working on the smallest detail. Even if the puzzler does not find anything in the end, he can still enjoy the path leading up to it.

The time-consuming and endless nature of scientific research appears in several ways, both in fiction and in non-fiction, among others, by stating that a result has "finally" been reached. Besides the time necessary to execute the work, there is the step-by-step approach to reach a result. This working attitude symbolises the systematic, inductive approach to science. Especially in fiction, the puzzler is the detective among scientists, who works systematically and does not fear time-consuming jobs. However, non-fiction authors also express that the scientist makes "frantic efforts" to find "evidence":

He asked himself when we could use this wonderful invention for the very first time (...) He put his Sherlock Holmes jacket on and dove into history, looking for traces that could explain the origins of language (Veld, 2009, p. 53).

The adventurer. The adventurer is the personification of the physically active scientist. $\mathrm{He}$, too, is willing to take risks to break new ground in science, for instance, to figure out how it is possible to build windmills in the sea (Het Klokhuis, July 2007) or how bombs can be 
cleaned up safely (Willem Wever, October 1995). This is in contrast to the puzzler, who prefers the seclusion of his study above a social life in order to be able to work at a "riddle". The riddles a puzzler tackles can also appear irrelevant or of little interest to an outsider. The riddles of an adventurer are much more appealing to one's imagination: they are mysterious, spectacular, valuable and therefore also valued. Like the geniuses in this typology, they take on the role of hero in fiction stories. In addition, the adventurer does not shun danger in order to unveil mysteries, to unravel them or to elucidate them. Moreover, the adventurer is willing to risk his life in the name of science.

Adventurous scientists are amply represented in fiction, as action is one of the characteristic ingredients of many fiction genres. In our sample, comic character professor Mortimer and professor Knap (who invented a flying super car) are examples of adventurers. Their job as a professor, their status, and their adventurous attitude serve as a catalyst for storytelling because these features enable them to travel to faraway places or make them privileged to solve problems. Furthermore, they are the right people to fight the mad scientists (e.g., in many stories of Blake en Mortimer). This struggle between good and evil scientists symbolises the dual and ambiguous attitude to scientific progress.

The mad scientist. The following three prototypes are associated with a different attitude towards science. If this attitude fits in with a perception of a threat to humanity, then it concerns the prototype of the mad scientist. In fiction, the motivation for the character's behaviour is formed by delusions of grandeur. The main characteristic of the mad scientist is the obsessive behaviour, directed at the execution of an insane plan. Generally, this plan is aimed against humanity, varying from the megalomaniac's plan to conquer the world to the creation of new life, whereby the scientist acts as if he were a god.

In general, the intellect of the mad scientist is negatively valued. Due to his obsessive focus on a certain aim, the scientist loses all sense of reality and the consequences are 
incalculable. The malicious behaviour of the mad scientist, but especially the disastrous consequences of his behaviour can alert the public to the immoral nature of particular developments in science, such as nuclear physics, genetic engineering and cloning.

In a fiction story, the mad scientist is very functional because he causes problems, so that the central hero's mission (sometimes a genius-scientist or an adventurer-scientist) is to restore the balance. For instance, in Bassie en Adriaan en de huilende professor, Professor Archibald Saggerijn invented "weeping gas", so that people would no longer need to waste energy by telling jokes and having fun. "There is enough gas to rule the world with a rod of iron (...) We need to cry! Be gone humour! Be gone laughing!” he cries (van den Ende and Verstraete, 1982).

Because of his functionality, the mad scientist is most apparent in fiction. However, we found some examples in non-fiction too, for instance, in the previously mentioned article from $K I J K$ (Piekart, 1998). In the article, the boss of the software giant Microsoft, Bill Gates, changes from a nerd into a dangerous madman. "Is the American super-nerd really a devilish, power-hungry person?" is the central question. Gates is portrayed as a tyrant with mankind as his victim: "Gates is the devil personified, a power-hungry person who wants to dominate the whole world, a monopolist taking delight in the wilful destruction of competitors" (p. 19). The prototypes of the nerd and of the mad scientist are rhetorically mobilised here to make a particular opinion about Gates plausible. This example is also an illustration of the fact that it is possible to approach a similar topic or scientist from different prototypes, and that each prototype mobilises a different set of connotations and opinions about a person or topic.

The wizard. If the attitude towards science is characterised not by distrust, but rather by (blind) faith in science, the wizard is the prototype concerned. The wizard is the personification of a perception that science is the best or even only way to solve problems, as the ultimate answer to all questions that society faces. 
There are important differences between the genius, the wizard and the mad scientist. The genius is more interested in the scientific process, in understanding how something works, while the wizard-scientist and the mad scientist are focused solely on the results or outcome. Whereas the genius will gladly share his ideas and the processes that lead to his find, for the wizard, the way in which the insight was reached is less important or will even be kept secret on purpose; only the result is important. The (realistic) scientific and technical process thus occupies a less central place for the wizard-scientist than for the genius. The genius also has status and power, while the mad scientist is especially after that power and wants to extort it. The wizard, on the contrary, does not (want to) attract attention, but operates in the background as helper. In fiction, the genius may be pictured as the central hero, while the wizard is more likely to be a supporting but crucial character that operates in the background: for example, he supplies the hero with a magic potion or a means of transportation so the hero can fulfil his quest, as, for instance, Professor Tournesol in Kuifje.

The misunderstood genius. Next to faith and a perception of threat, a third possible assessment of scientific outcomes is that they destabilise the existing world order. The misunderstood genius also embodies the anti-progress frame. In contrast to the mad scientist, however, sooner or later the misunderstood genius will be redeemed in the public's esteem. In non-fiction, there are sometimes references to the idea that the outside world or colleagues do not always immediately acknowledge brilliant ideas. The ideas and inventions are too complex, too absurd or too revolutionary so that acknowledgement follows only much later, possibly too late. For instance, in KIJK (Evenblij, 1996, p. 23), it is stated that, "For a long time, solar power cells were ridiculed".

The misunderstood genius is more prominent in fiction than in non-fiction. First, in combination with the mad scientist, the misunderstood genius may explain why the mad scientist might choose the side of evil. Second, the misunderstood genius gets in trouble when 
power elites consciously want to bring him into disrepute or others want to cash in on his inventions, as can be illustrated with the following dialogue between an inventor and his wife, taken from the Dutch children's movie Peter en de vliegende autobus:

Wife: After all these years of hard work, you finally receive the recognition you deserve!

Inventor: But don't you get it? Someone else wants the honours! (Van Balen and Van der Meulen, 1976).

\section{Relationships between the prototypes}

From the definitions of the prototypes above, five main defining characteristics of representations of science/scientists can be distilled: useful/useless; risky/safe; loner/team player; process-oriented/result-oriented; and eccentric/casual. These features provide additional insight in how the seven prototypes relate to each other.

Useful/useless. The first characteristic according to which the prototypes can be divided is connected with the use of science. It varies from the view that science is absolutely necessary to the view that it is completely useless. What the genius does is useful, whereas what the nerd, the mad scientist and the misunderstood genius accomplish is not useful (yet). The work of the puzzler can also sometimes seem useless.

Risky/safe. A next characteristic is related to the threat that may emanate from science. In the wider culture, images of science and technology as dangerous or the cause of problems can be seen, while science and technology are simultaneously presented as the solution (Van Loon, 2002). As already discussed, the mad scientist and the misunderstood genius are prototypes that personify the perception of scientific progress as potentially threatening. The wizard embodies faith in science, and the genius and adventurer can also be highly trusted. The nerd, finally, takes a mid-position on this scale. 
Loner/team player. The third characteristic relates to the position of the scientist as a loner or a team player. The competition and discussion between scientists and their ideas, but especially the working in a team, are aspects not normally included in the stereotypical image of science. According to most representations, science and technology are the work of one person. The other prototypes suggest that scientists are capable of doing amazing things (genius), that they are innocent and harmless (nerd), that they are taking responsible risks (adventurer), or that they will help humanity (wizard).

Most prototypes in our study are loners. Scientists are often depicted as loners, both at work and privately, especially in fiction. There are only a few exceptions. For instance, the professor in Peter en de vliegende autobus has a wife and a son who assist him in his laboratory. In non-fiction magazines, it is less exceptional to show that teamwork, joining forces, is often the key to success in science. Still, even in non-fiction, this is an exception rather than a rule. In some non-fiction stories, this dimension is expressed by emphasising the competitive character of science. This is expressed in several cases by emphasising that scientists are working on prototypes and inventions in total secrecy. They do that either because they want to be the first (more often in non-fiction) or, in fiction, because they fear that others have plans to lay their hands on the invention.

Process-oriented/result-oriented. A defining characteristic of all prototypes is their dedication to their profession: they work day and night, which suggests that their existence coincides with their scientific activities. There is hardly any time for a (social) life beyond work. The reason generally given is that they are inspired by an inherent drive, whereby the final results (the adventurer), as well as the process itself (the puzzler), provide satisfaction.

The work of the scientist requires a whole series of special features. In the first place, scientists have to be intelligent and able to make clever decisions fast. They also need to have endless patience to be able to focus on one specific question. The motivation of scientists and 
engineers to do everything within their power to reach their goal evokes awe and admiration, but equally incomprehension and howls of derision. According to the dominant representations of the scientist, especially in the exact sciences, he must be dedicated. The biologist running through the jungle after orang-utans and the climatologist staying in Antarctica can be portrayed as heroic adventurers, but the public may equally judge them insane. Having too strong a focus on a goal can lead to delusion, as is the case for the mad scientist. Indeed, most of the prototypes find themselves on the results-oriented side within the dimension of result - progress. For young people, this complete dedication, either to the end result or to the process, may be less attractive or less recognisable.

Eccentric/casual. A last characteristic draws on the eccentric/casual polarity. Although scientists may look casual, especially in non-fiction, in many cases, particularly in fiction, the artists and actors who need to visualise a scientist draw on a repertoire of external features, such as masculinity, fuzzy hair, a bushy beard, a bald head, thick glasses and an eccentric or old-fashioned style of clothing. Iconic images of scientists like Einstein and Darwin are likely to have served as inspiration for this recognisable appearance. This depiction facilitates fiction producers in making the scientist easily recognisable for the audience.

\section{Discussion}

The aim of this research was to gain insight into the prototypical scientists and engineers as they appear in the media consumed by young people in the Netherlands. Seven prototypes and their interrelation were analysed based on an inductive analysis. The seven prototypes can easily be recognised in fiction, especially the genius and the adventurer (the good heroes), the mad scientist (the enemy), and the wizard (the helper). As a result, the scientist is a useful character for people producing fiction. However, including in non-fiction magazines and television programmes, they are employed to present a recognisable image of 
science and technology to the audience. Both in fiction and non-fiction, the real life scientist can be pictured as the worst conceivable villain who wants to destroy the world, and just as credibly as a kind of saint who wants to help and supply solutions.

Some differences in the use of the prototypes in non-fiction and fiction can be noted and the described characteristics can shed light on them. The risk of science gets more attention in fiction than in non-fiction. Also, eccentric scientists appear more often in fiction since artists, film directors and actors can let their imaginations run free when creating these characters. Scientists in fiction can seldom be described as ordinary. In non-fiction, and especially in the genre of non-fiction magazines that we studied, the characteristic useful/useless is more important than in fiction. Particularly when science is described as costly, its social value is more often underlined. In fiction, the scientists have no money problems and can even afford a private laboratory in many cases, and so the characteristic useful/useless seems less of an issue. Another constant factor across the prototypes is that scientists are loners. This is also a theme in non-fiction, although here it is stressed more often, that scientists work in a team. A last dominant dimension in the description of scientists concerns the difference between the focus on getting results versus the process itself. Both fiction and non-fiction emphasise the result, the final product of a scientific mental process. LaFolette (1990) indicated in her typology of scientists that the prototype of the wizard, in particular, facilitates the presentation of a scientific accomplishment without having to understand it completely. In our study, the wizard refers to a type of scientist who you can blindly trust, who is entirely at the service of others, as the ultimate helper, without whose help the hero, or society, can make no progress.

In general, the image of the scientist in the Dutch media is physically unattractive, his work is often considered useless and/or unclear for laymen, he is dedicated and focused, non- 
sociable, not compliant with societal (or fashion) norms, and he is predominantly a white (old) man.

"Why would anyone embark on such a career?" is the question that young people probably ask themselves after seeing these representations. Feverishly working, not being sure whether success will be achieved or whether the result will be useful, running the risk of being called a madman or a nerd; all this prompts the question of what are the principal motives of scientists and engineers.

The idea that science might be useless can be of importance for the choice of study by young people (Schreiner and Sjoberg, 2005). The dominance of the characteristic that a scientist is not a team player is visible in drawings about science made by youth, in which secrecy is an often-encountered theme (Chambers, 1983). It is particularly this characteristic, the loneliness of science, which makes it less attractive for many pupils (Rommes et al., 2007). There seems to be a relation between science and suffering, as was discussed by Herzig (2005). Even young people who enjoy sciences may recognise themselves less in the complete devotedness often found in the prototypical depictions of the scientist. Finally, the representation that a scientist has an eccentric appearance makes it a less attractive profession for young people, who are at an age in which appearance is considered vitally important (Rasmussen, 1997). All in all, representations in the Dutch media create the image that science has to be a vocation or an obsession and that it can therefore not be an "ordinary" profession.

Based on this analysis, an alternative recruitment strategy to attract young people to science could be to invent new prototypes and emphasise positive aspects of the existing prototypes, like the fame and heroism of the genius and adventurer prototype. Compared to the other prototypes, adventurers may provide the greatest attraction to science for young people as adventures are engaged in exciting and even potentially dangerous things, especially 
in comparison with, for example, philosophers and sociologists. Similarly, the process of science rather than its outcomes could get more attention, as this will make science as a profession more imaginable.

A more nuanced and realistic image of science is more in line with the experiences of most scientists; for example, that they are people who are very inquisitive, sociable and who have lots of interests outside their profession. With regard to the profession, such a prototype would personalise scientific discussion and doubt. Even in non-fiction, we only rarely found indications that scientists are not completely sure, that they can only express inklings. In general, doubting is far from the most prevalent point of interest for non-specialist scientific magazines or television programmes. They deal mainly with the successes of science and technology. Hardly any attention is paid to failures. The dominant image is that scientists head straight towards their goal and believe in their results.

The futile search, the accumulative character of science and the accidental discoveries, characteristic of the doubter, very rarely appeared in our sample of media. Nevertheless, we have found one example, in a humorous sketch in the television programme Het Klokhuis. In one episode, Professor Alsvanouds (played by an actor) explains to the viewers how science is a lot of hard work without clear results and how you have to search endlessly. While he explains this to the viewers, he effortlessly and completely accidentally discovers what he is looking for, without him even realising it, which is what makes the sketch funny. We would call this rare prototype "the doubter", who could help to represent the scientific progress as more capricious and challenging, although how the prototype can personalise these characteristics attractively should be further developed.

For further research, it would be useful to look at which prototypes may reinforce a more popular and less distorted perception of science among young people. Whether the doubter is the most suitable prototype for presenting science as more attractive remains an 
open question. To be successful in recruiting young people, it seems that the characteristics of the doubter, or of the puzzler, need to be combined with the dynamic character of the adventurer and the usefulness of its rule with that of the wizard. 


\section{References}

Basalla G (1976) Pop science: The depiction of science in popular culture. In: Holton G and Blanpied WA (eds) Science and its public (pp. 261-278). Dordrecht: Reidel.

Chambers DW (1983) Stereotypic images of the scientist: The Draw-A-Scientist Test.

Science Education 67(2): 255-265.

Emons P, Wester F, and Scheepers P (2010) He works outside the home, she drinks coffee and does the dishes: Changes in gender roles in fiction programs on Dutch television. Journal of Broadcasting and Electronic Media 54(1): 40-53.

European Commission (2009) She figures 2009: Statistics and indicators on gender equality. Luxembourg: Publication Office of the European Union.

Evenblij M (1996, September) De zon wordt eindelijk serieus genomen [Finally, the sun is taken seriously]. Kijk, pp. 22-25.

Finson KD (2003) Applicability of the DAST-C to the images of scientists drawn by students of different racial groups. Journal of Elementary Science Education 15(1): 15-26.

Flicker E (2003) Between brains and breasts - women scientists in fiction film: on the marginalization and sexualization of scientific competence. Public Understanding of Science 12(3): 307-318.

Fralick B, Kearn J, Thompson S, and Lyons J (2008) How middle schoolers draw engineers and scientists. Science Education Technology 18: 60-73.

Hannover B, and Kessels U (2004). Self-to-prototype matching as a strategy for making academic choices: Why high school students do not like math and science. Learning and instruction 14: 51-67.

Haynes RD (2003) From alchemy to artificial intelligence: Stereotypes of the scientist in Western literature. Public Understanding of Science 12(3): 243-253.

Herzen F (2001) Professor Kopstuk [Children's book]. Antwerp: Zwijsen. 
Herzig RM (2005) Suffering for science: Reason and sacrifice in modern America. New Brunswick, NJ: Rutgers University Press.

Hirsch W (1958) The image of the scientist in science fiction: A content analysis. American Journal of Sociology 63: 506-512.

Hottois G (1984) Le signe et la technique. La philosophie à l'épreuve de la technique. Paris: Aubier Montaigne.

Ihde D, and Selinger E (eds) (2003) Chasing Technoscience: Matrix for materiality. Bloomington, IN: Indiana University Press.

Kessels U (2005) Fitting into the stereotype: How gender-stereotyped perceptions of prototypic peers relate to liking for school subjects. European Journal of Psychology of Education 20(3): 309-323.

Kitzinger J, Haran J, Chimba M, and Boyce T (2008) Role models in the media: An exploration of the views and experiences of women in science, engineering and technology. Bradford, UK: UK Resource Centre for Women in Science, Engineering and Technology (UKRC).

LaFollette MC (1990) Making science our own: Public images of science 1910-1955.

Chicago, IL: The University of Chicago Press.

Lafosse-Marin MO, and Laguës M (2007) Dessine- moi un scientifique. Paris: Belin.

Long M and Steinke J (1996) The thrill of everyday science: images of science and scientists on children's educational science programmes in the United States. Public Understanding of Science 5: 101-119.

Michel LP, and Pelka B (2004) Die Darstellung von Berufen im Fernsehen und ihre Auswirkungen auf die Berufswahl - Ergebnisse einer Pilotstudie. Essen, Berlin, Germany: MMB, Institut für Medien- und Kompetenzforschung.

Piekart F (1998, May) Bill\$ wil is wet [Bill's word is law]. Kijk, pp. 18-21. 
Propp VJ (1958) Morphology of the folktale. Bloomington: Indiana University.

Rasmussen B (1997) Girls and computer science: 'It's not me. I'm not interested in sitting behind a machine all day'. In AF Grundy, D Köhler, V Oechtering, and U Petersen (Eds.), Women, work and computerization: Spinning a web from past to future (pp. 379386). Bonn, Germany: Springer.

Rommes E, Overbeek G, Scholte R, Engels R, and de Kemp, R (2007) 'I'm not interested in computers': Gender-based occupational choices of teenagers. Information, Communication \& Society 10(3): 299-319.

Rommes E, and Schönberger M (2009) Report WP 4 Motivation. Wuppertal, Germany: EU Coordinated Action Motivation.

Rompa B (2008) Uitvinder Otto en de slakmobiel [Inventor Otto and the snail vehicle, Children's book]. Hasselt, Belgium: Clavis.

Schreiner C, and Sjoberg S (2005) Science education and young people's identity construction. Two mutually incompatible projects? Nordic Studies in Science Education. 2: $1-17$.

Steinke J (2005) Cultural Representations of Gender and Science: Portrayals of Female Scientists and Engineers in Popular Films. Science Communication, 27(1), 27-63. Turney J (1998) Frankenstein's footsteps: Science, genetics, and popular culture. New Haven, CT: Yale University Press.

Van Balen F (Producer), and Van der Meulen K (Director) (1976) Peter en de vliegende autobus [Peter and the flying bus, Motion picture]. The Netherlands: Caster Films. Van den Berg K, de Lange M, Westerhof H, Loos AL, and Braam RR (2003) Wetenschapsen techniek-communicatie in kengetallen: Een eerste exercitie. Amsterdam: Stichting Weten. 
Van den Ende J (Producer), and Verstraete G (Director) (1982) Bassie en Adriaan en de huilende professor [Bassie and Adriaan and the weeping professor, TV Series]. The Netherlands: Adrina \& Bassie Producties / Bridge Entertainment Group.

Van Lieshout T et al. (Writer), and Postma R et al. (Director) (2009, May) The particle accelerator at CERN, Geneva [Television series episode]. In Brinkman J (Producer), Het Klokhuis. Hilversum, the Netherlands: NTR.

Van Loon J (2002) Risk and technological culture: Towards a sociology of virulence. London: Routledge.

Veld V (2009, June) Zoeken naar woorden [Searching for words]. Quest, pp. 52-55.

Weingart P (2003) Of power maniacs and unethical geniuses: Science and scientists in fiction film. Public Understanding of Science 12(279-287).

Working Group on the Declining Interest in Science and Technology (S\&T) (2006) Evolving student interest in science and technology studies [Policy Report]. S.1.: Organisation for Economic Co-operation and Development, Global Science Forum. 
Table 1: Characteristics of scientists in fiction and non-fiction, and how they relate to prototypes of scientists

\begin{tabular}{|c|c|c|c|}
\hline Non-fiction & Fiction & Prototype & Visuals \& symbols \\
\hline $\begin{array}{l}\text { Intelligence, } \\
\text { exceptional } \\
\text { achievements }\end{array}$ & $\begin{array}{l}\text { Extraordinary and } \\
\text { revolutionary } \\
\text { inventions (often } \\
\text { means of } \\
\text { transportation) }\end{array}$ & Genius & $\begin{array}{l}\text { Fantastic inventions; } \\
\text { light bulb (bright } \\
\text { idea) }\end{array}$ \\
\hline \multirow[t]{2}{*}{$\begin{array}{l}\text { Disengagement from } \\
\text { the material world }\end{array}$} & $\begin{array}{l}\text { Absent-mindedness; } \\
\text { extraordinary } \\
\text { inventions that } \\
\text { mistakenly hinder the } \\
\text { hero of the story }\end{array}$ & Genius, wizard & Distracted gaze \\
\hline & Socially inept & Nerd & $\begin{array}{l}\text { ICT setting; } \\
\text { unfashionable } \\
\text { appearance }\end{array}$ \\
\hline $\begin{array}{l}\text { Time-consuming } \\
\text { character of science; } \\
\text { the scientific method: } \\
\text { gradual and } \\
\text { empirical approach, } \\
\text { testing of theories, } \\
\text { gathering of new data }\end{array}$ & $\begin{array}{l}\text { Systematic collection } \\
\text { of clues, like a } \\
\text { detective }\end{array}$ & Puzzler & $\begin{array}{l}\text { Magnifying glass, } \\
\text { microscope, library } \\
\text { with thick books; } \\
\text { searching } \\
\text { meticulously; long } \\
\text { beard }\end{array}$ \\
\hline $\begin{array}{l}\text { Exploring, } \\
\text { discovering new } \\
\text { species and } \\
\text { territories, the } \\
\text { willingness to give } \\
\text { his life for science, } \\
\text { self-sacrifice and } \\
\text { dedication }\end{array}$ & $\begin{array}{l}\text { Expeditions to exotic } \\
\text { places and new } \\
\text { worlds }\end{array}$ & Adventurer & $\begin{array}{l}\text { Physically active } \\
\text { scientist; } \\
\text { transpiration, pith } \\
\text { helmet, butterfly net }\end{array}$ \\
\hline
\end{tabular}




\begin{tabular}{|c|c|c|c|}
\hline $\begin{array}{l}\text { Discoveries, } \\
\text { knowledge and } \\
\text { inventions that help } \\
\text { advance humanity } \\
\text { (progress frame) }\end{array}$ & $\begin{array}{l}\text { Special inventions } \\
\text { that assist the story's } \\
\text { hero to solve } \\
\text { problems }\end{array}$ & Wizard & $\begin{array}{l}\text { Operating on the } \\
\text { background, often } \\
\text { invisible }\end{array}$ \\
\hline $\begin{array}{l}\text { Discoveries, } \\
\text { knowledge and } \\
\text { inventions that } \\
\text { threaten humanity } \\
\text { (anti-progress frame) }\end{array}$ & $\begin{array}{l}\text { Special inventions } \\
\text { and plans that pose a } \\
\text { big risk (linked to } \\
\text { delusions of } \\
\text { grandeur) }\end{array}$ & Mad scientist & $\begin{array}{l}\text { Explosions, diseases, } \\
\text { disasters; eccentric } \\
\text { appearance, grim } \\
\text { face }\end{array}$ \\
\hline $\begin{array}{l}\text { Discoveries, } \\
\text { knowledge and } \\
\text { inventions that may } \\
\text { pose a danger to } \\
\text { humanity or } \\
\text { destabilise the } \\
\text { existing } \\
\text { order/equilibrium } \\
\text { (anti-progress frame) }\end{array}$ & $\begin{array}{l}\text { Making } \\
\text { extraordinary } \\
\text { discoveries that } \\
\text { rulers/power elites } \\
\text { perceive as } \\
\text { threatening to their } \\
\text { position and status }\end{array}$ & $\begin{array}{l}\text { Misunderstood } \\
\text { genius }\end{array}$ & Eccentric appearance \\
\hline
\end{tabular}

